\title{
OPTIMIZATION OF ENZYMATIC HYDROLYSIS OF FISH PROTEIN HYDROLYSATE (FPH) PROCESSING FROM WASTE OF CATFISH FILLET PRODUCTION
}

\section{Optimasi Proses Hidrolisa Ensimatis pada Pembuatan Hidrolisat Protein Ikan (HPI) dari Limbah Filet Ikan Patin}

\author{
Bagus Sediadi Bandol Utomo ${ }^{1 *}$, Theresia Dwi Suryaningrum ${ }^{1}$ and Herbert R. Harianto ${ }^{2}$ \\ ${ }^{*}$ Research and Development Center for Marine and Fisheries Product Processing and Biotechnology, \\ JI. KS Tubun Petamburan VI, Central Jakarta, Indonesia \\ ${ }^{2}$ Graduate, Faculty of Life Science, Swiss-German University, BSD-Serpong, Banten, Indonesia \\ *Correspondence Author: bagus_sbu@yahoo.com \\ Article history: \\ Received: 18 August 2014; Revised: 2 September 2014; Accepted: 16 Oktober 2014
}

\begin{abstract}
An experiment to determine the optimum condition of fish protein hydrolysate (FPH) processing has been conducted to produce FPH with high protein content. The raw material was catfish (Pangasius sp.) waste from catfish fillet production. Fat content, sensory (color, odor and flavor), total number of bacteria (TPC) and E. coli were analyzed as supporting parameters. The experiment was initiated with preliminary experiment to determine the optimum temperature (temp variation: $50^{\circ} \mathrm{C}, 55^{\circ} \mathrm{C}, 60^{\circ} \mathrm{C}$, and $65^{\circ} \mathrm{C}$ ) and concentration of commercial papain enzyme (conc variation: $4 \%$, $6 \%$, and $8 \%$ ) in $\mathrm{FPH}$ hydrolysis, while the main experiment was to determine the optimum time of hydrolysis (time variation: $6,12,24,36$, and 48 hours), and $\mathrm{pH}$ ( $\mathrm{pH}$ variation: 5 and 7). Results showed that the optimum temperature in preliminary experiment was $60^{\circ} \mathrm{C}$ and optimum concentration of enzyme was $4 \%$, whereas the main experiment resulted the optimum hydrolysis time of 48 hours and optimum pH of 5 . This condition produced FPH with protein content of $1.21 \%$ wet weight basis $(w b)$ or $39.03 \%$ dry weight basis $(\mathrm{db})$ and fat content of $0.16 \% \mathrm{wb}(5.16 \% \mathrm{db})$. The sensory analysis of the end product revealed that from max score of 5 , the scores of color, odor and flavor of the FPH were 3.50, 2.17 and 2.29, respectively. The product had TPC of 1.1x $10^{7} \mathrm{CFU} / \mathrm{g}$ with no E. coli infection.
\end{abstract}

Keywords: Fish Protein Hydrolysate (FPH), pangasius waste, papain, hydrolysis

\begin{abstract}
ABSTRAK
Penelitian untuk mencari kondisi optimum pembuatan hidrolisat protein ikan (HPI) telah dilakukan untuk mendapatkan HPI dengan kandungan protein tinggi. Bahan baku yang digunakan adalah limbah ikan patin (Pangasius sp.) dari pengolahan filet ikan patin. Kadar lemak, sensori (warna, bau dan rasa), angka lempeng total (ALT) dan E. coli dianalisa sebagai parameter pendukung. Percobaan didahului dengan percobaan pendahuluan untuk menentukan suhu optimum hidrolisis $\mathrm{FPH}$ (variasi suhu: $50^{\circ} \mathrm{C}, 55^{\circ} \mathrm{C}, 60^{\circ} \mathrm{C}, 65^{\circ} \mathrm{C}$ ) dan konsentrasi ensim papain (variasi konsentrasi: 4\%,6\%,8\%), sedangkan percobaan utama bertujuan untuk menentukan waktu optimum hidrolisis (variasi waktu: 6, 12, 24, 36, dan 48 jam), dan $\mathrm{pH}$ (variasi pH: 5 dan 7). Hasil menunjukkan bahwa suhu optimum hidrolisis pada percobaan pendahuluan adalah $60^{\circ} \mathrm{C}$ dan konsentrasi ensim optimum adalah 4\%. Percobaan utama menghasilkan waktu hidrolisis optimum 48 jam dan $\mathrm{pH}$ optimum 5 . Kondisi ini menghasilkan FPH dengan kandungan protein $1,21 \%$ berat basah (bb) atau 39,03\% berat kering (bk) dan kandungan lemak 0,16\% bb (5,16\% bk). Nilai organoleptik FPH yang dihasilkan yaitu warna, bau dan rasa masing-masing adalah 3,50; 2,17; dan 2,29 (dari nilai tertinggi 5) dengan kandungan ALT 1,1 x 10 $\mathrm{CFU} / \mathrm{g}$ dan sama sekali tidak mengandung bakteri $E$. coli.
\end{abstract}

Kata Kunci: Hidrolisat Protein Ikan (HPI), limbah pangasius, papain, hidrolisis

Permalink/DOI: http://10.15578/squalen.v9i3.79

\section{Introduction}

Catfish (Pangasius sp.) is a freshwater fish which has a long silver body with blue color on the back side. Indonesia has been promoting catfish culture program in the last years, in 2012 catfish production in Indonesia was 347.000 tons (DGAF, 2013), mostly exported to U.S. and European countries in the form of processed products. Most of fisheries industries use only the meat part of fish, which constitute only 
approximately $40 \%$ of total fish weight, the rest being fish waste of about $50 \%-60 \%$ of total fish weight. The waste can be processed into fish protein hydrolysate (FPH).

According to Pigott and Tucker (1990), fish protein hydrolysate is a liquid product made from fish with the addition of proteolytic enzymes to accelerate the hydrolysis process in controlled conditions with the end result of a mixture of protein components. FPH can be used as food supplement or could be eaten directly as food to improve the protein intake. This product could play an important role in reducing protein deficiency in many parts of the world where large numbers of the population suffer from malnutrition. Chalamaiah et al. (2012) stated that fish protein hydrolysates were breakdown products of enzymatic conversion of fish proteins into smaller peptides, which normally contain 2-20 amino acids.

FPH has also been reported by Wergedahl et al. (2004) that this product was very potential for nutritional or pharmaceutical applications. Pigott and Tucker (1990) stated that nutritive studies have shown the remarkable beneficial effect of adding $\mathrm{FPH}$ to the people diet particularly for children and pregnant mothers.

The most efficient way to produce FPH is by enzymatic hydrolysis, because it produces high noncomplex peptide content which is easily to break down in the intestine. Rustad et al. (2011) stated that by using enzyme technology, it is possible to produce various types of food ingredients and according to Bhaskar et al. (2008), hydrolysis process using acid or bases could denature the product and some amino acids and produce some toxic compounds. Ibarra et al. (2013) produced fish protein hydrolysate from minced salmon muscle using food grade alcalase 2.4 $\mathrm{L}$ enzyme, the FPH was used to enhance water retention in sous vide processing of salmon. Bhaskar and Mahendrakar (2008) also studied the optimization of enzymatic hydrolysis of visceral waste protein of catla (Catla catla) for preparing protein hydrolysate using a commercial protease (alcalase). It was found that the proportion of enzyme to substrate of $1.5 \%(\mathrm{v} /$ $\mathrm{w}), \mathrm{pH} 8.5$, temperature of $50^{\circ} \mathrm{C}$ and hydrolysis time of 135 min was the optimum condition to obtain a higher degree of hydrolysis close to $50 \%$.

Protein hydrolysate was also prepared by Bhaskar et al. (2007) from pre-treated sheep visceral mass by enzymic treatment at $43{ }^{\circ} \mathrm{C}$ and $\mathrm{pH} 7$ using fungal protease. The optimum hydrolysis time was $45 \mathrm{~min}$, producing 6\% (w/w) yield of protein hydrolysate.

Fitzgerald et al. (2005) have intensively studied the preparative properties of a commercial fish protein hydrolysate preparation. The studies have shown bioactivity of the product in a variety of gut integrity and repair models.

In the production of protein hydrolysate, several factors affect the speed and specificity of hydrolysis products, namely temperature, hydrolysis time and enzyme concentration. Hydrolysis time is the most influential factor for the quality of the resulting hydrolysate. Overtime hydrolysis will causes decrease in number of peptides and amino acids and increase in nonfunctional residue (Pigott \& Tucker, 1990).

The end product of protein hydrolysate can be liquid, paste or powder. Several methods for producing protein hydrolysate are already available but enzymatic hydrolysis is considered more appropriate and cheaper, faster and producing product without having to lose a lot of essential amino acids. However, the enzyme should be chosen correctly according to the end product required. Production experiment of $\mathrm{FPH}$ using alcalase and flavourzyme enzymes had been conducted by Muzaifa et al. (2012). Most of the protein hydrolysate has bitter flavor, therofore some type of flavoring agent need to be used in the fortification of food to cover the bitter taste.

Benhabiles et al. (2012) studied optimization of fish protein hydrolysate production from sardine solid waste by crude pepsin enzymatic hydrolysis in a bioreactor coupled to an ultrafiltration unit. It was found that the optimum conditions for enzymatic reaction were using temperature $48^{\circ} \mathrm{C}$ and $\mathrm{pH} 1.5$.

Physicochemical properties of silver catfish (Pangasius sp.) frame hydrolysate has also been studied by Amiza et al. (2013). The study found that preparation of these hydrolysates affected the protein, ash and fat content as well as amino acid composition. The suggested hydrolysis conditions to obtain optimum degree of hydrolysis for silver catfish frame using alcalase were temperature of $58^{\circ} \mathrm{C}$, hydrolysis time of $134 \mathrm{~min}, \mathrm{pH}$ of substrate at 9.4 and enzyme concentration of $8.3 \%$.

Papain enzyme plays important role in hydrolysis process of fish into FPH by accelerating the rate of reaction of biochemical process within cells and tissue at optimal $\mathrm{pH}$, temperature and concentration which made the enzyme to work efficiently. Without enzyme, the biochemical process of breaking down protein of fish into FPH would take very long time.

According to Winarno and Hwa (1964) papain has exceptional stability to heat at neutral $\mathrm{pH}$ and to some organic solvent; it is the major protein in aqueous phase of papaya latex at $\pm 5 \%$ concentration. It can be spray dried at $\pm 65^{\circ} \mathrm{C}$ without loss of enzyme activity. In dried form, papain forms a crystal like with coarse granule and white in color. Crude papain has a 
characteristic of being insoluble in water, easy to be separated. Papain enzyme has best activity at $\mathrm{pH} 5-$ 7 with temperature ranging from $50^{\circ} \mathrm{C}$ to $60^{\circ} \mathrm{C}$. Papain will lose its activity at temperature of $75^{\circ} \mathrm{C}-85^{\circ} \mathrm{C}$.

The primary purpose of this experiment is to use catfish (Pangasius sp.) waste as raw materials to produce fish protein hydrolysate $(\mathrm{FPH})$ and to determine the optimum condition of fish waste hydrolysis process to produce high protein content $\mathrm{FPH}$.

\section{Material and Methods}

\subsection{Material}

The raw material used in this experiment was catfish (Pangasius sp.) waste obtained from fillet production. The study was conducted at Research Center for Marine and Fisheries Product Processing and Biotechnology, Jakarta, Indonesia. The enzyme used was commercial local crude papain enzyme "PAYA" having activity of $1.0593 \mathrm{U} / \mathrm{g}$ as measured by Darwis et al. (1995).

\subsection{Methods}

\subsubsection{Hydrolysis procedure}

Catfish waste was firstly minced and then mixed with water with ratio of $1: 2$ by weight, the mixture was blended and homogenized to improve the hydrolysis reaction. The homogenate was then added with papain enzyme of $4 \%$ concentration, devided into two parts and then adjusted to $\mathrm{pH} 5$ and $\mathrm{pH} 7$ with $2 \mathrm{~N}$ $\mathrm{HCl}$. The experiment was initiated with preliminary experiment to determine the optimum temperature (temp variation: $50^{\circ} \mathrm{C}, 55^{\circ} \mathrm{C}, 60^{\circ} \mathrm{C}$, and $65^{\circ} \mathrm{C}$ ) in $\mathrm{FPH}$ hydrolysis. The end product was filtered, to produce $\mathrm{FPH}$. The end product was then analyzed (protein content, and organoleptic test). Product with the highest score was then analyzed for its amino acid composition and microbiological quality (TPC and E. coli).

\subsubsection{Chemical analysis}

Water content was analyzed by drying the sample at temperature of $105^{\circ} \mathrm{C}$ for 5 hours according to SNI 01-2354.2-2006 (BSN, 2006b); ash content was analyzed by drying the sample at temperature of 100 ${ }^{\circ} \mathrm{C}$ for 24 hours, then it was further heated in a furnace at $550{ }^{\circ} \mathrm{C}$ for 8 hours based on SNI 01-2354.1-2006 (BSN, 2006a); fat content was analyzed using soxlet method based on SNI 01-2354.3-2006 (BSN, 2006c) by extracting the samples at $60^{\circ} \mathrm{C}$ for 8 hours, then further heated in an oven at $105^{\circ} \mathrm{C}$ for 2 hours. Protein content was analyzed by distruction and distillation method based on SNI 01-2354.4-2006 (BSN, 2006d). The destruction process was done at $410{ }^{\circ} \mathrm{C}$ for 2 hour before distillated and titrated using Kjeltec 2300 (FOSS).

\subsubsection{Microbiology analysis}

For total plate count test, repeated sample dilution using plate count agar (PCA) was applied. The samples were incubated in aerobic condition at $22^{\circ} \mathrm{C}$ for 48 hours. E. coli test was conducted using repeated dilution of the sample in phosphate buffer, using lauryl tryptose broth (LTB) equipped with Durham tube. The samples were incubated for 48 hours at $35^{\circ} \mathrm{C}$ and examined after 48 hours of incubation. Sample with positive indications were inoculated into test tube with EC broth. Positive results were marked with gas formed inside Durham tube and the EC broth color turned into dark color. The most probable number (MPN) method was applied to calculate the number of bacteria.

\subsubsection{Organoleptic test}

The end products were tested for its flavor, odor, and color appearance by trained panelist. Open discussion method was used to determine the score sheet for each parameter tested. Then samples from preliminary experiment were tested by panelist in closed testing by ranking method, and hedonic test. The results were then analyzed and sample with highest organoleptic score was chosen as base parameter for main experiment.

For organoleptic test of main experiment, same member of panelist were used to analyze the samples. Ranking test was also included for main experiment to determine product accepted by panelist. Ranking test was done by using hedonic scale ranged $1-5$. The use of same panelist as before was to minimize bias in organoleptic test. The best FPH product was chosen based on the highest score of total parameters tested.

\subsection{Experimental Design}

\subsubsection{Preliminary experiment}

Factorial design with two factors was used in the preliminary experiment to identify the effect of enzyme concentration and hydrolysis temperature. Enzyme concentrations used for hydrolysis process were $4 \%$, $6 \%, 8 \%$, while hydrolysis temperatures were $50{ }^{\circ} \mathrm{C}$, $55^{\circ} \mathrm{C}, 60{ }^{\circ} \mathrm{C}$, and $65{ }^{\circ} \mathrm{C}$. The best result from preliminary experiment based on flavor, color and odor selected by trained panelists was then used for primary experiment. 
Table 1. Proximate Analysis of Catfish (Pangasius sp.)'s fillet waste

\begin{tabular}{lc}
\hline \multicolumn{1}{c}{ Type of Analysis } & Results \\
\hline Moisture content & $(67.05 \pm 5.13) \%$ \\
Ash content & $(0.82 \pm 0.31) \%$ \\
Fat content & $(18.00 \pm 1.00) \%$ \\
Protein content & $(12.51 \pm 10.5) \%$ \\
\hline
\end{tabular}

\subsubsection{Primary experiment}

In the primary experiment, factorial design with two factors and three replications was also used to identify the effect of different hydrolysis time and $\mathrm{pH}$. The hydrolysis time was varied from $6,12,24,36$ and 48 hours, and $\mathrm{pH}$ of hydrolysis used were 5 , and 7 . The best result was chosen from the product with the highest protein content.

\section{Results and Discussion}

\subsection{Preliminary Experiment}

Analysis of the raw material (waste of Pangasius $\mathrm{sp}$. fillet) was conducted to identify the chemical character of catfish waste including moisture, ash, fat and protein content. Results of proximate analysis of Catfish's fillet waste is shown in Table 1.

The waste was including heads, bones, meat trimmings, belly meat, liver and viscera of Pangasius $\mathrm{sp}$. The protein content of the waste was lower than catfish meat used by Chaijana et al. (2010) for their experiment but the fat content was much higher. The protein, fat and ash content of the different parts of farm raised giant catfish (Pangasianodon gigas) muscle averaged $16.88,4.45$ and $1.24 \%$, respectively. However, this protein content was close to that of catfish (Pangasius hypophthalamus) used by Hafiz (2009) for his experiment ie. 14.54\%. The protein content of the raw material used in this experiment was slightly lower than the average normal fish because the waste includes bones from the catfish.

\subsubsection{Organoleptic analysis}

Results from organoleptic analysis of preliminary experiment shows that there was a significant difference within each treatment of hydrolysis. Results showed that hydrolysis of catfish waste with $4 \%$ enzyme concentration and at $60^{\circ} \mathrm{C}$ gave the highest score of 4.72 . The lowest score is obtained by hydrolysis treatment with $4 \%$ enzyme concentration at $50^{\circ} \mathrm{C}$ with score of 1.33 . Panelist recognized that treatment with $8 \%$ enzyme concentration at $60^{\circ} \mathrm{C}$ produce FPH product with salty flavor. Since the enzyme used for the experiment was commercial enzyme that often used as meat tenderizer, salt might

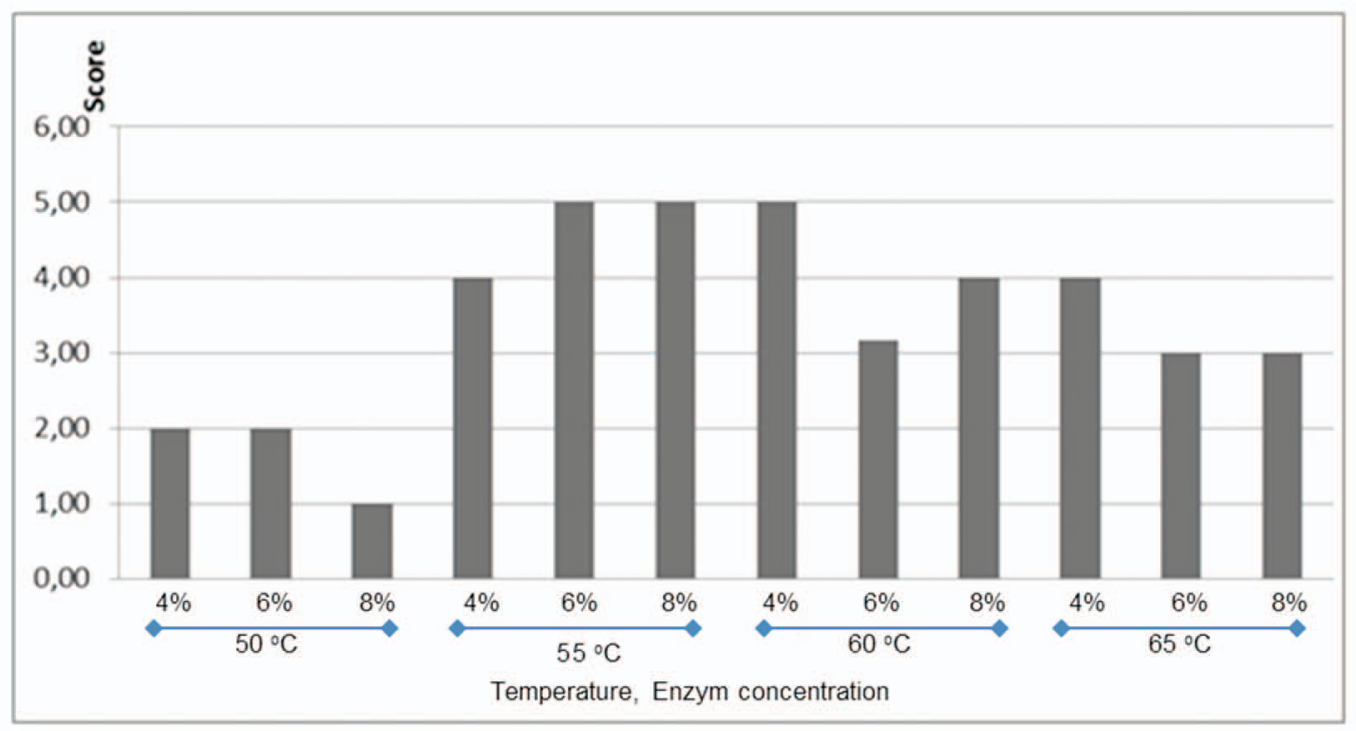

Note : score 5 = very like; score 1 = very dislike

Figure 1. Color score of FPH in preliminary experiment. 
be added by the producer to enhance flavor of the product.

Figure 1 shows the score given by panelist in term of color for preliminary experiment. From Figure 1 above, hydrolysis temperature of $55^{\circ} \mathrm{C}$ with $8 \%$ concentration and $60{ }^{\circ} \mathrm{C}$ with $4 \%$ concentration received the highest average score in term of color with value of 5 , while the lowest score was given to $50^{\circ} \mathrm{C}$ hydrolysis temperature with value of 1.

Figure 2 shows that the highest average score of odor was obtained by the combination of $4 \%$ enzyme at $60{ }^{\circ} \mathrm{C}$ with value of 4.67 . The lowest average score was obtained by combination of $4 \%, 6 \%$ enzyme concentration at $50{ }^{\circ} \mathrm{C}$ with value of 1 . The score for odor parameter tested tends to increase in line with increase in hydrolysis temperature. Starting from $50^{\circ} \mathrm{C}$ with score ranging from $1-2$, this value continues to increase to score ranging $3-4$ at $55{ }^{\circ} \mathrm{C}$. While the highest score was obtained at temperature of $60^{\circ} \mathrm{C}$ with score ranging from 4.6-3.

Figure 3 shows that the highest average score for flavor was obtained by combination of $8 \%$ enzyme concentration at $55^{\circ} \mathrm{C}$ temperature with value of 5 . The lowest average score was obtained at $50{ }^{\circ} \mathrm{C}$ temperature with all three enzyme concentration with value of 1 . From Figure 3, the score given by panelist tends to rise in line with increase in temperature as in $55{ }^{\circ} \mathrm{C}$ with value range between 3-5 and continued with temperature at $60^{\circ} \mathrm{C}$ with score ranging between 4.2-3.3.

\subsubsection{Determination of hydrolysis parameters}

From the result of organoleptic analysis, it show that catfish waste which were hydrolyzed with $4 \%$ enzyme concentration at $60^{\circ} \mathrm{C}$ temperature gave the highest score in term of odor, flavor, and color given by trained panelist. According to Saputra (2008), the optimum enzyme concentration for hydrolysis process of yellow fish by using papain is at $0.2 \%$, with temperature of $60{ }^{\circ} \mathrm{C}$. Hydrolysis time of yellow fish starts from 2, 4 to 6 hours and the protein content of FPH product is increasing with relative to hydrolysis time. Therefore, hydrolysis time of $6,12,24,36,48$ hours were used to study the optimum hydrolysis condition.

\subsection{Primary Experiment: Hydrolysis of Catfish Waste}

As preliminary results, in this primary research, the hydrolysis temperature used was $60{ }^{\circ} \mathrm{C}$ and concentration of the enzyme used was $4 \%$. Using papain enzyme from commercial meat tenderizer product named "PAYA", catfish waste hydrolysis was performed using various treatment of $\mathrm{pH}$ and hydrolysis time.

\subsubsection{Protein content}

Figure 4 shows the protein content of FPH produced from hydrolysis of catfish waste at various hydrolysis time and $\mathrm{pH}$. After being hydrolyzed for 6 hours at $\mathrm{pH} 5$ the protein content of the FPH was only $0.23 \%$ and after 48 hours was $1.21 \%$. The protein content increased with increasing hydrolysis time. Based on ANOVA analysis, there was a significant difference in protein content in FPH product at different hydrolysis time in each hydrolysis time.

This result proved that hydrolysis time gave significant effect on protein content of FPH product. The highest protein content is produced at hydrolysis

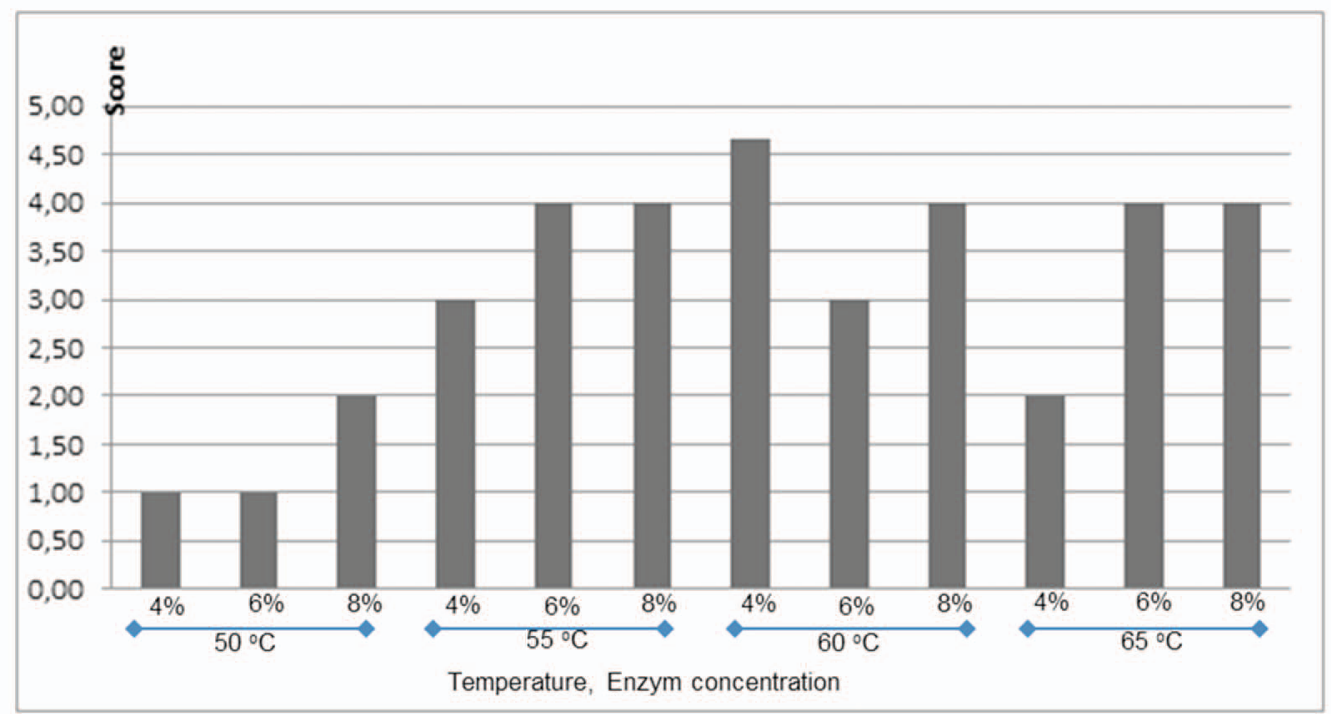

Note : score 5 = very like; score 1 = very dislike

Figure 2. Odor score of FPH in preliminary experiment. 


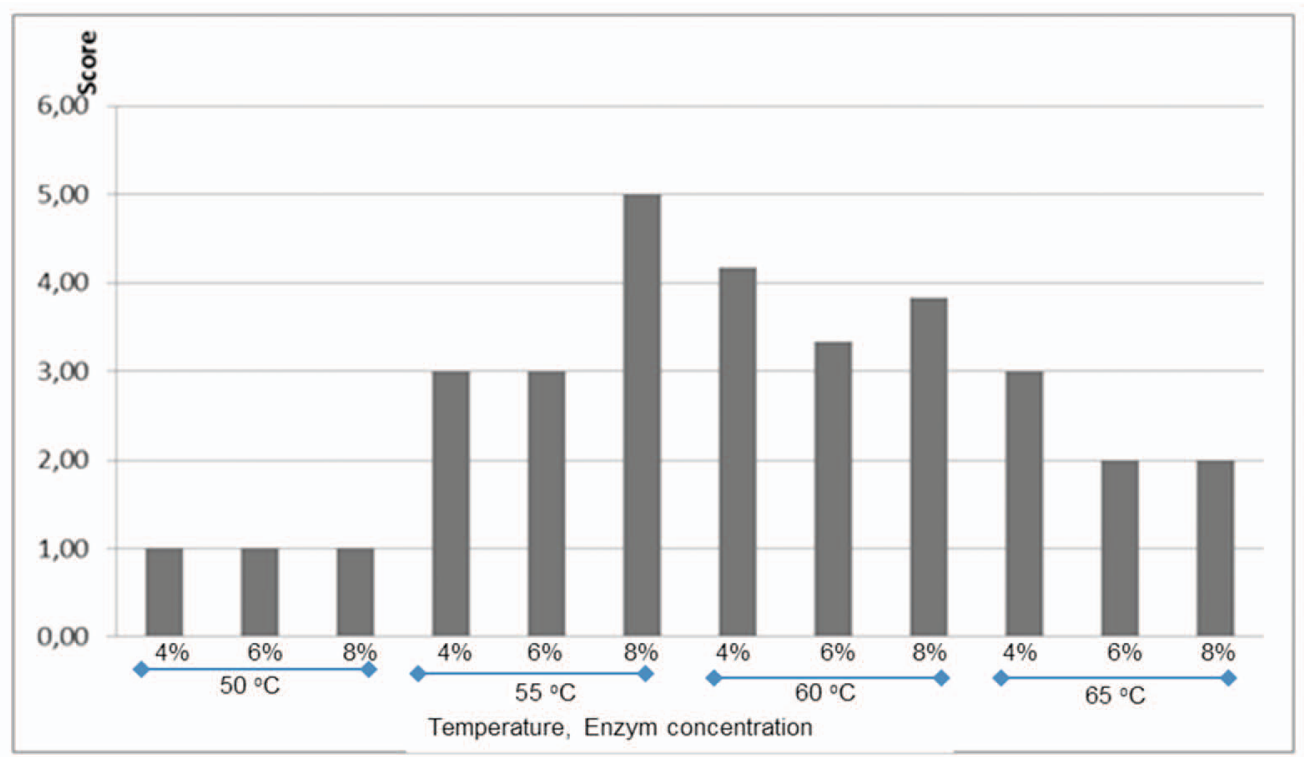

Note: score 5 = very like; score 1 = very dislike

Figure 3. Flavor score of FPH in preliminary experiment.

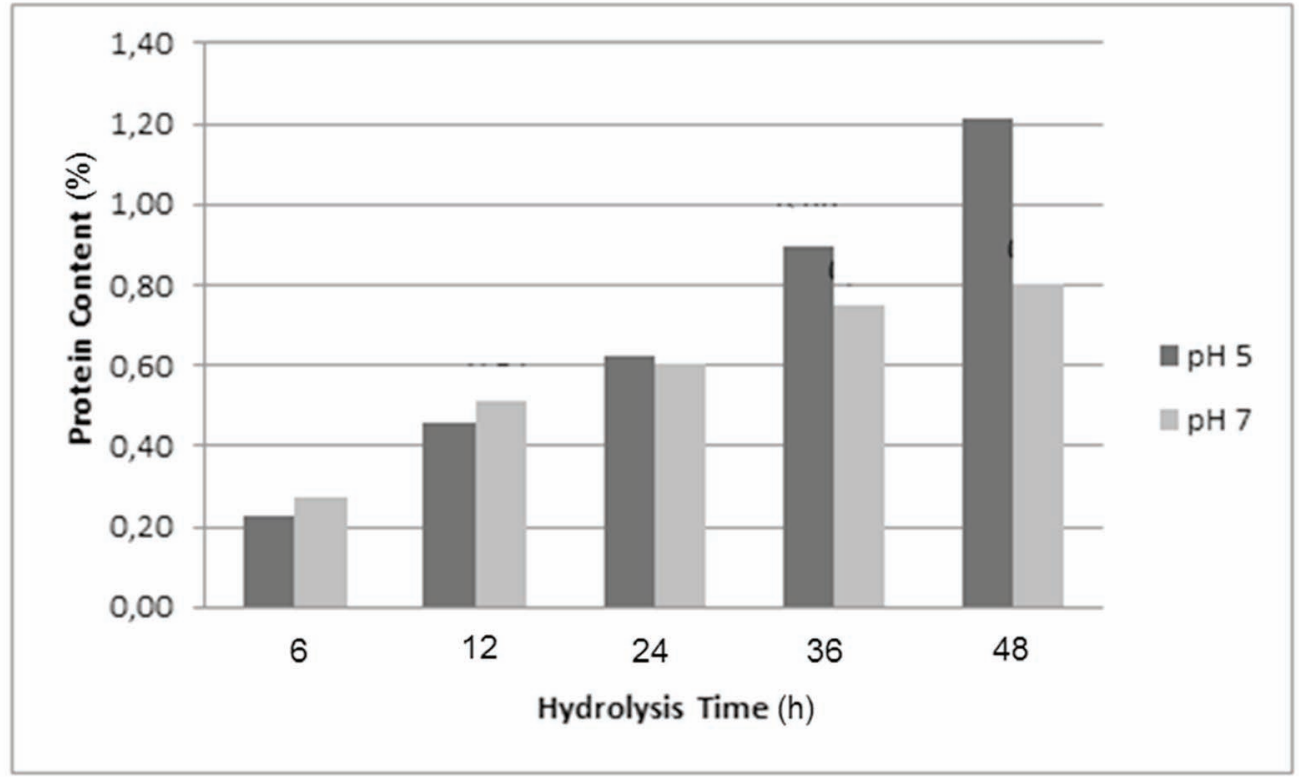

Figure 4. Protein content of FPH during hydrolysis at $\mathrm{pH} 5$ and 7.

time of 48 hours with $1.21 \%$ (Figure 4). The catfish waste had been transformed into dilute slurry starting from 6 hours of the hydrolysis process. The process of hydrolysis of raw materials (catfish waste) is mainly caused by the activity of papain enzyme. The highest protein concentration was obtained when the hydrolysis time was 48 hours.

Similar to the hydrolysis process at $\mathrm{pH} 5$, the protein content of the $\mathrm{FPH}$ hydrolyzed at $\mathrm{pH} 7$ tended to increase with increasing hydrolysis time. After being hydrolyzed for hours the protein content of the FPH was only $0.27 \%$ and at the end of hydrolysis the protein content of FHP was $0.80 \%$. There was also significant difference in protein content in FPH product at different hydrolysis time at $\mathrm{pH}$ 7. Result showed that at hydrolysis time of 24 hours the protein content was $0.60 \%$, it was not significantly different from treatment of 12 hours with protein content of $0.51 \%$. Result from t-test support the statement from Duncan post hoc test that there was no significant difference $(>0.05)$ in protein content between hydrolysis time of 12 hours and 24 hours. From this result, hydrolysis time became the determining factor of hydrolysis process and influenced the work of enzymes to react with the 
substrate. As stated earlier by Chalamaiah et al., (2012) that fish protein hydrolysates were breakdown products of enzymatic conversion of fish proteins into smaller peptides, which normally contain 2-20 amino acids. Enzymes require longer time to react with protein and work to hydrolyze protein into amino acids. From the statistical analysis, there was no significant difference $(>0.05)$ among replication in the treatment of the experiment. Analysis using two-way ANOVA showed that there was no interaction between $\mathrm{pH}$ of treatment and hydrolysis time in terms of protein content of the FPH produced. This result also showed that $\mathrm{pH}$ does not give significant effect to protein content of the product. The highest protein content of the FPH from the experiment was only $1.21 \%$ wet weight basis or $39.03 \%$ dry weight basis. This is still much lower than the protein content of the FPH produced from fish by-product prepared using alcalase enzyme ie. $82.66 \%$ dry weight basis and that prepared using flavourzyme enzyme ie. $73.51 \%$ dry weight basis (Muzaifa et al., 2012).

\subsubsection{Fat content}

The average fat content of FPH product in $\mathrm{pH} 5$ treatment at different hydrolysis time is shown in Figure 5.

There was a significant difference $(<0.05)$ in fat content in $\mathrm{FPH}$ product at different hydrolysis time in each hydrolysis time in $\mathrm{pH} 5$. This result is expected since FPH product is cooled until oil from hydrolysis process turns into fat to be separated from the product manually by hand. Hence the amount of fat taken out from each hydrolysis time was significant difference. According to Duncan post hoc test the highest fat content from FPH product was produced at hydrolysis time of 6 hours with $0.44 \%$.
There was a significant difference $(<0.05)$ in fat content in FPH product at different hydrolysis time in each hydrolysis time in $\mathrm{pH} 7$ (Figure 6). There was no significant difference $(>0.05)$ in replication of treatment which yield generally same fat content with each replication.

\subsubsection{Organoleptic analysis of main experiment}

Organoleptic test was conducted by the same panelist as in the preliminary experiment.

\section{Color}

Color is the first properties in sensory analysis that can be directly measured by the panelist. The average score given by panelists in term of color parameter with comparison between treatment $(\mathrm{pH} 5$ and 7) and hydrolysis time is shown in Figure 7.

Figure 7 shows that hydrolysis with $\mathrm{pH} 5$ treatment on average receive higher score given by panelist. Figure 7 shows that the average highest score of color (4.83) was obtained by hydrolysis time of 24 hours with $\mathrm{pH}$ 5. While the lowest score (3.50) for $\mathrm{pH} 5$ treatment is obtained by hydrolysis time of 48 hours. Hydrolysis process with $\mathrm{pH} 7$ treatment receives score of 4.57 for 6 and 12 hours hydrolysis time. Score declined for $\mathrm{pH} 7$ at 24 hours hydrolysis time with value of 3.71 , and at 36 hours with value of 3.00 . While at 48 hours hydrolysis time for $\mathrm{pH} 7$ treatments the value was at 3.14. The level of color of $\mathrm{FPH}$ product is determined by thickness level of oxymyoglobin at the surface of raw material during hydrolysis process. Myoglobin and oxymyoglobin undergoes rapid oxidation process so it would quickly transform its color into brown yellowish color and produce metmyoglobin as by product of myoglobin denature

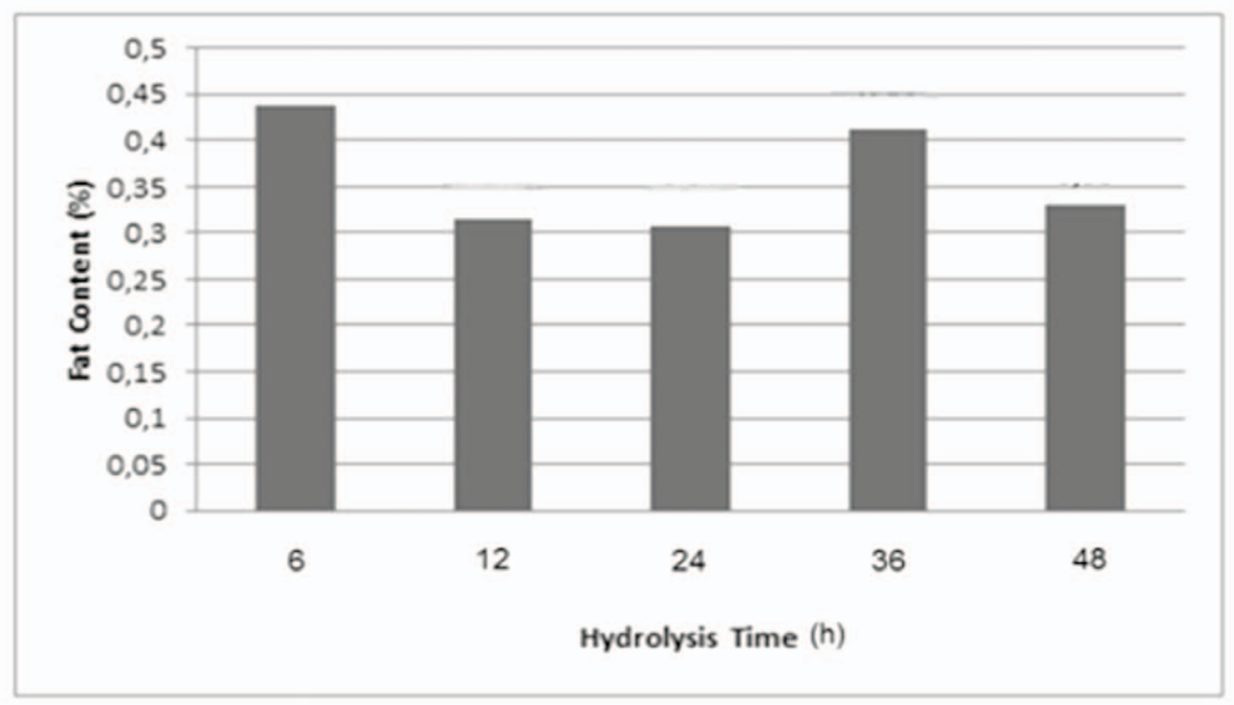

Figure 5. Fat content of $\mathrm{FPH}$ processed in $\mathrm{pH} 5$. 


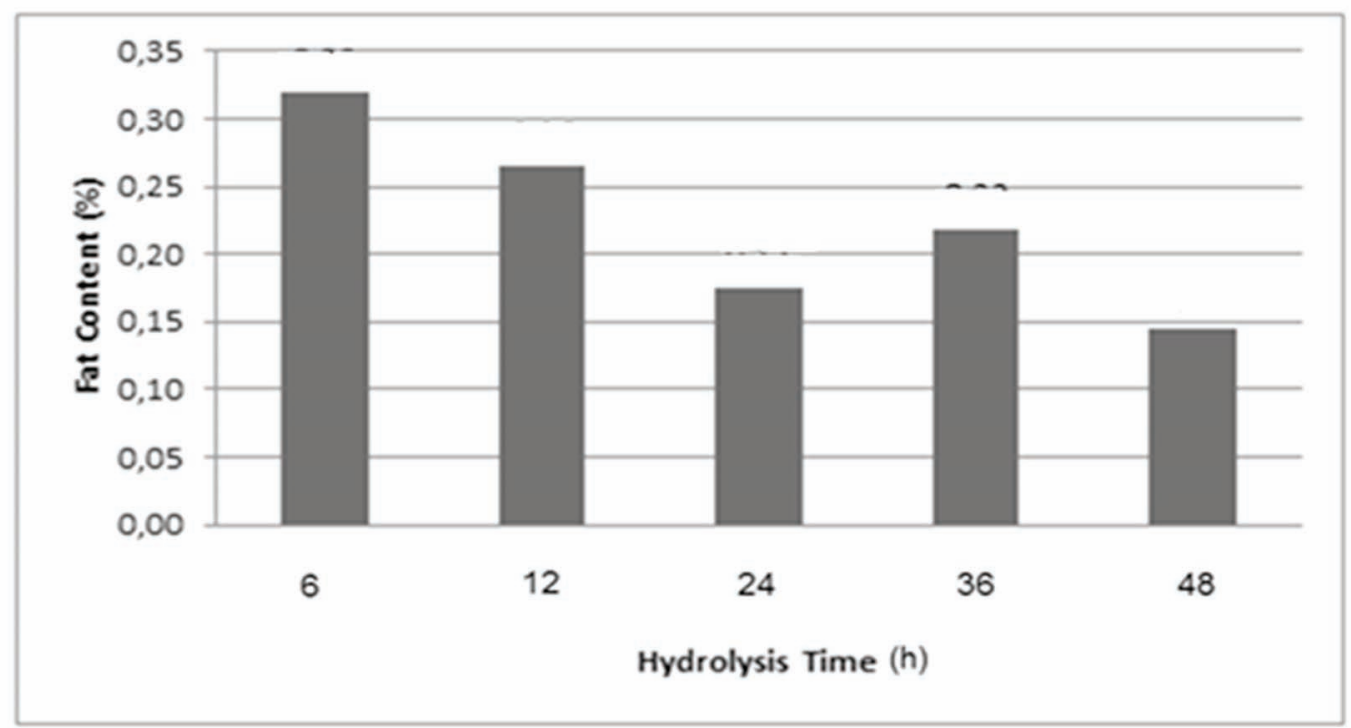

Figure 6. Fat content of $\mathrm{FPH}$ processed in $\mathrm{pH} 7$.

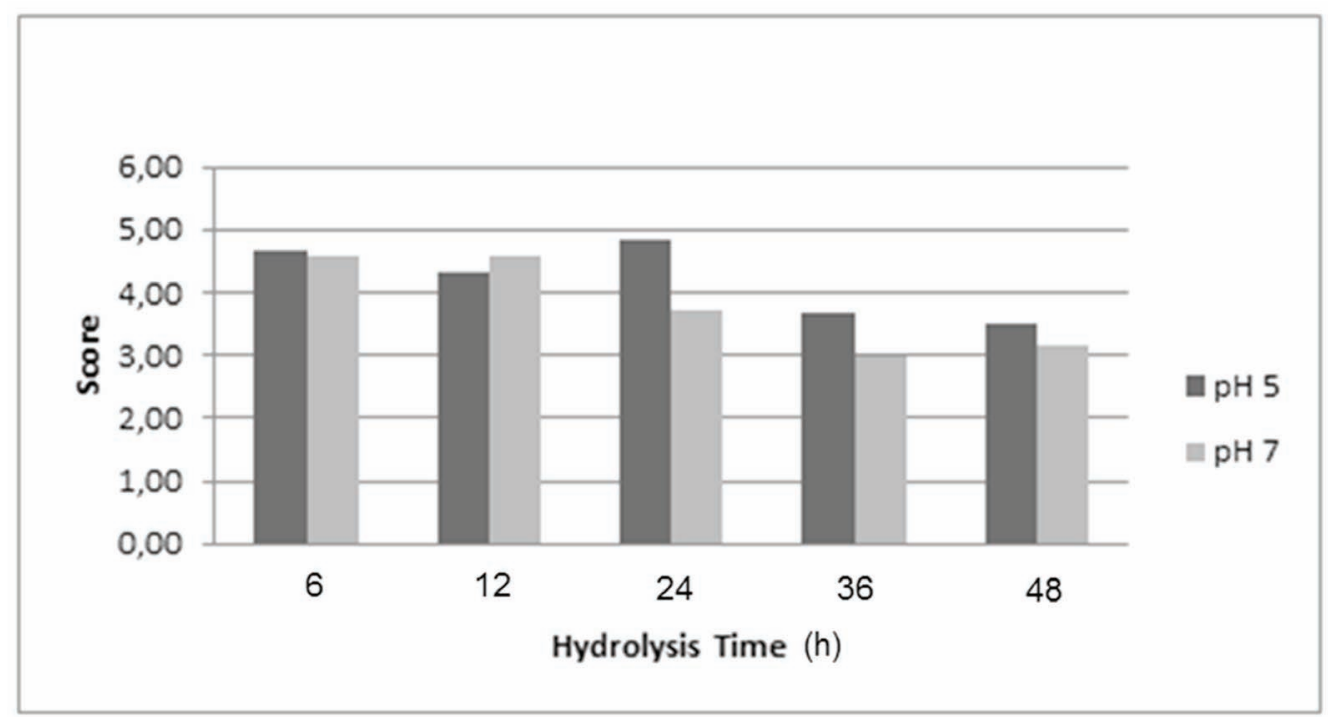

Note: score 5 = very like; score 1 = very dislike

Figure 7. Color score of FPH in main experiment.

during heating of tissue (Buckle et al., 1987). Cooking process cause myoglobin denatures and transform into metmygolbin with brown color (Boles \& Pegg 2008).

\section{Odor}

Score given for parameter of odor was determined by olfactory organ, since olfactory organ has sensors that are very specific for smell. In general the parameter of odor that can be accepted by human consists of 4 type of odor such as fragrant, acidic, rancid, and scorched (Winarno, 1997).
The highest score for odor is obtained by $\mathrm{pH} 5$ hydrolysis treatments, with the highest score at 12 and 24 hours hydrolysis time with value of 4.5 . The lowest score obtained by $\mathrm{pH} 5$ hydrolysis treatment is at 48 hours hydrolysis time with value of 2.17. For $\mathrm{pH} 7$ treatment the highest score was obtained at 12 hours hydrolysis time with value of 4.43 , and the lowest score is obtained at 36 hours of hydrolysis time with value of 1.86 (Figure 8). Fishy odor is caused by transformation of lecithin into trimetil-amine groups (Herlina \& Ginting, 2002). According to Fardiaz (1992), the breakdown of protein release compound with rancid 
or pungent arome such as hydrogen sulfide, mercaptan, indol, skatol, putresin, and kadaverin.

\section{Flavor}

Figure 9 shows that the average highest score for flavor was obtained for hydrolysis with $\mathrm{pH} 5$ treatment with value of 4.83 at 6 hours hydrolysis time. While the lowest flavor score for $\mathrm{pH} 5$ was obtained at 48 hours hydrolysis time with value of 2.17. The score for flavor of FPH product tested tends to decline as hydrolysis time increases. The highest score for $\mathrm{pH} 7$ treatment was obtained at 6 hours hydrolysis time that with value of 4.29 , while the lowest score was obtained at 48 hours hydrolysis time with value of 2.29. For both $\mathrm{pH}$ treatments the highest average score was obtained at 6 hours hydrolysis time that may be caused with high content of glutamic acid. According to West and Todd (1964), FPH product contains high glutamic acid content which gives them umami taste, therefore FPH is often used as flavor enhancer.

Longer hydrolysis time would produce the by product from process of protein breakdown such as

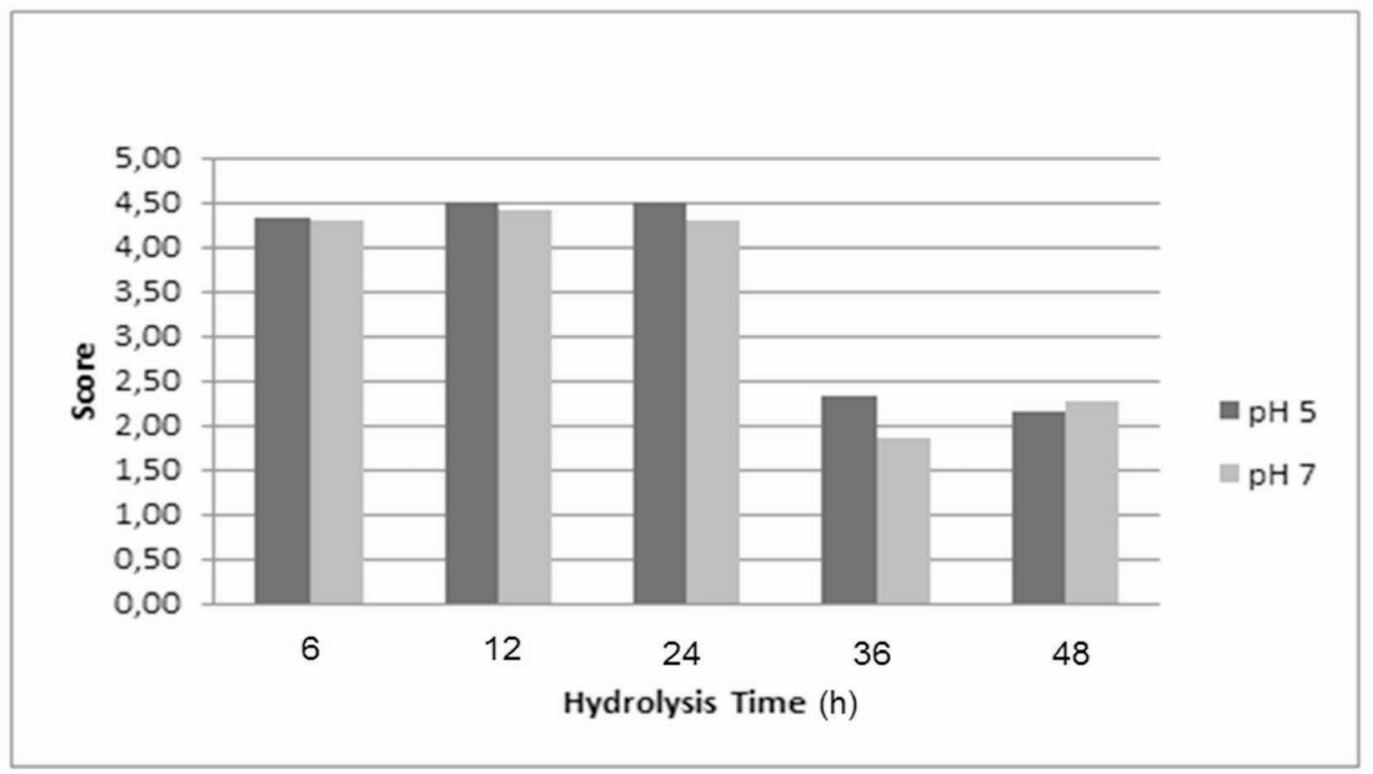

Note : score 5 = very like; score 1 = very dislike

Figure 8. Odor score of FPH in main experiment.

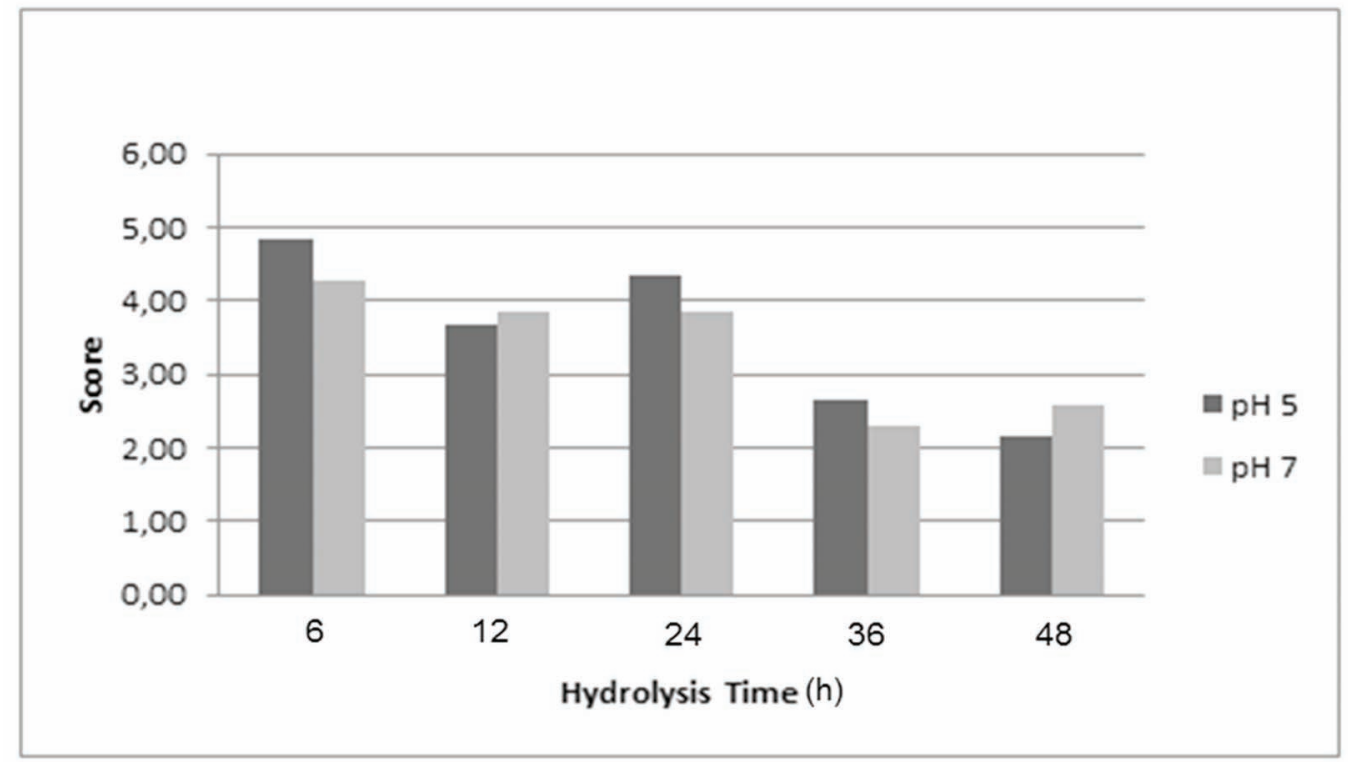

Note : score 5 = very like; score 1 = very dislike

Figure 9. Flavor score of $\mathrm{FPH}$ in main experiment. 
hydrogen sulfide, mercaptan, indol, skatol, putresin, and kadaverin. The releases of such by product that produce pungent or rancid smell prevent the willingness of panelist to test the sample. Some panelist stated for hydrolysis time of 48 hours at both $\mathrm{pH}$ treatment the odor of sample is rotten, this give suggestion to the panelist that the sample was already rotten and prevent them to test the sample.

\subsubsection{Ranking test}

The test shows that FPH product from 6 hours hydrolysis time ranked first score with value of 1.43 , followed by 24 hours with score of 1.86 , while hydrolysis of catfish waste for 12 hours have value of 2.71. Hydrolysis for 36 hours receives score of 4.14 from panelist. The last ranking (rejected) was hydrolysis time for 48 hours who obtaining a value of 4.86. While for samples treated with $\mathrm{pH} 7$, product with hydrolysis time of 6 hours had ranked first score by panelist with score of 1.57 , followed by 24 hours of hydrolysis time with score of 2.14 , and hydrolysis time of 12 hours receive score of 2.29 from panelist. While hydrolysis time of 48 hours receive score of 4.14 from panelist. Hydrolysis time of 36 hours was ranked last (rejected) by the panelist with score of 4.86 .

\subsubsection{Microbial growth}

\section{Bacterial Count}

Results show that hydrolysis process reduces the number of bacteria from catfish waste. The raw material used in the experiment contains $1.4 \times 10^{8} \mathrm{CFU} / \mathrm{g}$ while the product contains only $1.1 \times 10^{7} \mathrm{CFU} / \mathrm{g}$. It could be that some bacteria are not resistant to heating temperature up to $60^{\circ} \mathrm{C}$.

\section{E. coli Test}

Based on E. coli test result, there was no E. coli contamination to FPH product and only some coliform exist within end product. The FPH product contains 21 numbers of coli form/sample. Without $E$.coli found within the product, it showed that hydrolysis at $60^{\circ} \mathrm{C}$ is capable of killing pathogenic microbes, as stated by Stumbo (1965) that E. coli have Thermal Death Time (TDT) at $57.3^{\circ} \mathrm{C}$ for $20-30$ minutes. Microbes can be partially or completely eliminated by heat treatment; however the time and temperature used are dependent on the type and number of microorganism. Vegetative cells of yeast and fungi are not very heat resistant and are generally killed at temperatures of $50-70{ }^{\circ} \mathrm{C}$. Vegetative cells of thermophyles and thermo resistant organisms are resistant to these temperatures. Yeast ascospores and most mold spores are also inactivated at $60^{\circ} \mathrm{C}$ in
10-15 minutes (Stumbo, 1965). Spoilage in low acid foods is often caused by thermophilic species of Bacillus; such as $B$. coagulans and $B$. sterothermophilus. These organisms produce acid without gas (Desrosier, 1970). Spoilage mostly occurs in low and medium acid foods. C. thermos accharolyticum is an obligate thermophile and therefore needs hot storage for its development. Sulphide spoilage (sulphur stinker) is caused by Clostridium nigrificans in low acid foods.

\section{Conclusion}

The optimum temperature for FPH hydrolisis of catfish waste was $60{ }^{\circ} \mathrm{C}, \mathrm{pH} 5$, papain enzyme concentration was $4 \%(\mathrm{w} / \mathrm{w})$, and time of hydrolysis was 48 hours. Different $\mathrm{pH}$ treatment did not give significant difference in protein content of the product, and the highest protein content of FPH produced under optimum condition was $39.03 \%$

\section{References}

Amiza, M. A., Ow, Y. W., \& Faazaz, A. L. (2013). Physicochemical Properties of silver Catfish (Pangasius sp) Frame Hydrolysate. International Food Research Journal, 20(3), 1255-1262.

Ball, C. \& Oslon, O. (1957). Sterilization in Food Technology. Mcgraw-hill Co. New York.

Benhabiles, M. S., Abdi, N., Drouiche, N., Lounici,H., Pauss, A., Goosen, M. F. A., \& Mamen, N. (2012). Fish Protein Hydrolysate Production from Sardine Solid Waste by Crude Pepsin Enzymatic Hydrolysis in a bioreactor Coupled to an Ultrafiltration Unit. Materials Science and Engineering, 32(4), 922-928.

Bhaskar, N., Benila, T., Radha, C., \& Lalitha, R. G. (2007). Optimization of Enzymatic Hydrolysis of Visceral Waste Protein of Catla (Catla catla) for Preparing Protein Hydrolysate Using a Commercial Protease. Bioresource Technology, 99(2), 335-343.

Bhaskar, N. \& Mahendrakar, N. S. (2008). Protein Hydrolysate from Visceral Waste Protein of Catla (Catla catla): Optimization of Hydrolysis Conditions for a Commercial Neutral Protease. Bioresource Technology, 99(10), 4105-4111.

Bhaskar, N., Modi, V. K., Govindaraju, K., Radha, C., \& Lalitha, R. G. (2007). Utilization of Meat Industry by Products: Protein Hydrolysate from Sheep Visceral Mass. Bioresource Technology, 98(2), 388-394.

Boles, J. A. \& Pegg, R. (2008). Meat Color. Montana State University and Saskatchewan Food Product Innovation Program. Retrieved from http// www.animalrange. montana.educoursemeatmeatcol. pdf. Accessed on June, $13^{\text {th }} 2010$.

BSN. (2006a). Cara uji kimia - Bagian 1: Penentuan kadar abu pada produk perikanan. (Test methods of chemistry - Part 1: The determination of ash content in fishery products) Badan Standardisasi Nasional 
Indonesia (National Standardisation Agency of Indonesia). Jakarta. 9p.

BSN. (2006b). Cara uji kimia - Bagian 2: Penentuan kadar air pada produk perikanan. (Test methods of chemistry - Part 2: The determination of water content in fishery products). Badan Standardisasi Nasional Indonesia (National Standardisation Agency of Indonesia). Jakarta. 8p.

BSN. (2006c). Cara uji kimia - Bagian 3: Penentuan kadar lemak total pada produk perikana (Test methods of chemistry - Part 3: The determination of total lipid content in fishery products). Badan Standardisasi Nasional Indonesia (National Standardisation Agency of Indonesia). Jakarta. 8p.

BSN. (2006d). Cara uji kimia - Bagian 4: Penentuan kadar protein dengan metode total nitrogen pada produk perikanan. (Test methods of chemistry - Part 4: The determination of protein content in fishery products by nitrogen total methods) Badan Standardisasi Nasional Indonesia (National Standardisation Agency of Indonesia). Jakarta. 10p.

Buckle, K. A., Edwards, R. A., Fleet, G. A., \& Wootton, M., (1987). Ilmu Pangan. Purnomo, H.A. Translation. UI Press. Jakarta.

Chaijana, M., Jongjareonrakb, A., Phatcharatc, S., Benjakulc, S., \& Rawdkuend, S. (2010). Chemical compositions and characteristics of farm raised giant catfish (Pangasianodon gigas) muscle. LWT-Food Science and Technology, 43(3), 452-457.

Chalamaiah, M., Kumar, B. D., Hemalatha, R., \& Jyothirmayi, T. (2012). Fish protein hydrolysates: Proximate composition, amino acid composition, antioxidant activities and applications: A review. Food Chemistry (Birch ed.), 135(4), 3020-3038.

Darwis, A. A., Suryani, A., Perangiangin, R., \& Kusnaeni, S. (1995). Pembuatan hidrolisat protein ikan menggunakan enzim papain untuk suplemen protein pada mie. Jurnal Teknologi Industri Pertanian, V(2), 64-130.

Desrosier, N. W. (1970). Technology of Food Preservation. Westport, Connecticut: AVI Pub. Co

DGAF. (2013). Aquaculture Fisheries Statistics. Directorate General of Aquaculture Fisheries. Ministry of Marine Affairs and Fisheries. Jakarta. 2013.

Fardiaz, D. (1992). Mikrobiologi pengolahan Pangan Lanjut. IPB, Bogor.
Fitzgerald, A. J., Rai, P. S., Marchbank, T., Tayler, G. W., Ghosh, S., Ritz, B. W., \& Playford, R.J. (2005). Preparative Properties of a Commercial Fish Protein Hydrolysate Preparation. Gut. Jun, 54(6), 775-781.

Hafiz, M. (2009). Karakterisasi Surimi Ikan Patin (Pangasius hypophthalamus). Thesis. Departemen Teknologi Hasil Perairan. Fakultas Perikanan dan Ilmu Kelautan. IPB. Bogor.

Herlina, M. T. \& Ginting, M. S. H. (2002). Lemak dan Minyak. Jurusan Teknik Kimia. Fakultas Teknik Universitas Sumatera Utara. Medan.

Ibarra, J. P., Teixeira, A., Simpson, R., Valencia, P., Pinto, M., \& Almonacid, S. (2013). Addition of Fish Protein Hydrolysate for Enhanced Water Retention in Sous Vide Processing of Salmon. J. Food Process Technol., 4-7.

Muzaifa, M., Safriani, N., \& Zakaria, F. (2012). Production of protein hydrolysates from fish by-product prepared by enzymic hydrolysis. International Journal of the Bioflux Society. Aquaculture, Aquarium, Conservation \& Legislation, 5(1), 36-39.

Pigott, G. M. \& Tucker, B. W. (1990). Utility Fish Flesh Effectively While Maintaining Nutritional Qualities. Seafood Effects of Technology and Nutrition. Marcel Decker, Inc., New York.

Rustad, T., Storro, I., \& Slizyte, R. (2011). Possibilities for the utilization of marine by-product. Internat. Journal of Food Science and Technology, 46, 2001-2014.

Saputra, D. (2008). Pembuatan pepton ikan selar (Caranx leptoleptis) hasil tangkap sampingan (HTS) pada kondisi post rigor dan busuk. Fakultas Perikanan dan IImu Kelautan. IPB. Bogor.

Stumbo, C. R. (1965). Thermobacteriology in Food Processing. New York. Academic Press.

Wergedahl, H., Liaset, B., Gudbrandsen, O. A., Lied, E., Espe, M., \& Muna, Z. (2004). Fish Protein Hydrolysate Reduces Plasma Total Cholesterol, Increases the Proportion of HDL, Cholesterol and Lowers Acyl-CoA: Cholersterol Acytransferase activity in Liver of Zucker Rats. Journal of Nutrition, 134, 1320-1327.

West, E. S. \& Todd, W. C. (1964). Textbook of Biochemistry. New York. The Mac Millan, Co.

Winarno, F. G. (1997). Kimia Pangan dan Gizi. PT. Gramedia Pustaka Utama. Jakarta.

Winarno, F. G. \& Hwa, T. G. (1964). Papain dan Penggunaannya untuk Pengempukan Daging. Fakultas Tenkologi dan Mekanisasi Pertanian. IPB. Bogor. 
Squalen Bulletin of Marine \& Fisheries Postharvest \& Biotechnology, 9 (3), 2014, 107-114 